\title{
Representasi Maskulinitas pada Sosok Ayah dalam Film (Studi Semiotika Roland Barthes pada Film Fatherhood)
}

\author{
Winardi Aldrian', Suzy S. Azeharie ${ }^{2 *}$ \\ ${ }^{1}$ Fakultas Ilmu Komunikasi, Universitas Tarumanagara, Jakarta \\ Email: winardi27a@gmail.com \\ ${ }^{2}$ Fakultas Ilmu Komunikasi, Universitas Tarumanagara, Jakarta* \\ Email: suzya@fikom.untar.ac.id
}

Masuk tanggal : 15-12-2021, revisi tanggal :06-01-2022, diterima untuk diterbitkan tanggal :06-01-2022

\begin{abstract}
Film is the dominant form of visual mass communication in this world. In general, films are built upon signs, which include images and sounds. On June 18, 2021, Netflix released the comedy drama film Fatherhood. This film tells the story of a father who has to live as a single father who has to perform a domestic role by taking care of a child, as well as being an architect as his public role. This study aims to find out the representation of masculinity in father figure on Fatherhood. The theory used by author in this study is mass communication theory, film as mass media, Netflix, Roland Barthes's semiotic, representation, gender and masculinity. This research uses a descriptive qualitative approach with Roland Barthes's semiotic model analysis technique. The research data were obtained from scenes or texts in film, observations, and literature studies. The conclusion of this study is that the masculinity in father figure on "Fatherhood" is represented through three aspects, namely the domestic role that's associated with the concept of male masculinity as a "new man as nurturer" and the concept of fatherhood, the public role which is the role of the men with masculinity and societal views that's related to patriarchal ideology.
\end{abstract}

Keywords: film, masculinity, Roland Barthes, semiotics

\begin{abstract}
Abstrak
Film merupakan bentuk dominan dari komunikasi massa visual dalam dunia. Pada umumnya film dibangun dengan tanda-tanda meliputi gambar dan suara. Pada tanggal 18 Juni 2021, Netflix merilis film drama komedi yang berjudul Fatherhood. Film ini menceritakan tentang seorang ayah yang harus menjalani hidup sebagai ayah tunggal yang melakukan peran domestik dengan mengasuh anak sekaligus peran publik yaitu bekerja sebagai arsitek. Tujuan penelitian ini adalah untuk mengetahui representasi maskulinitas pada sosok ayah dalam film Fatherhood. Teori yang digunakan penulis dalam penelitian ini adalah teori media massa, film sebagai media massa, Netflix, semiotika Roland Barthes, representasi, gender dan maskulinitas. Penelitian ini menggunakan pendekatan penelitian kualitatif deskriptif dengan teknik analisis semiotika model Roland Barthes. Data penelitian diperoleh dari adegan-adegan atau teks pada film, observasi pada film, dokumentasi, dan studi kepustakaan. Kesimpulan pada penelitian ini adalah maskulinitas pada sosok ayah dalam film Fatherhood direpresentasikan melalui tiga hal, yaitu peran domestik yang berhubungan konsep maskulinitas laki-laki sebagai "new man as nurturer" dan konsep fatherhood, peran publik yang merupakan peran laki-laki dengan maskulinitasnya dan pandangan masyarakat yang berkaitan dengan ideologi patriarki.
\end{abstract}

Kata Kunci: film, maskulinitas, Roland Barthes, semiotika 


\section{Pendahuluan}

Film merupakan bentuk dominan dari komunikasi massa visual dalam dunia (Ardianto, 2012). Film menurut Irwanto dalam Alex Sobur merekam realitas yang berkembang serta bertumbuh dalam masyarakat dan diproyeksikan ke atas layar. Film juga memiliki kekuatan dan kemampuan untuk menjangkau banyak segmen sosial dan menjadikan film berpotensi memengaruhi khalayak. Secara umum film dibangun dengan tanda-tanda (Sobur, 2020).

Dalam kaitannya dengan tanda, representasi mempunyai kegunaan yaitu tanda untuk melukiskan pengertian akan suatu hal dalam bentuk fisik dengan cara memproses berbagai rekaman ide dalam beberapa cara fisik. Hasil pemaknaan setiap manusia dapat berbeda karena berbagai cara pandang dan pola pikir yang dimiliki manusia berbeda satu sama lain (Angela dan Winduwati, 2019).

Film menghadirkan berbagai genre seperti drama, komedi, horror, aksi, fantasi, religius dan lain sebagainya. Berdasarkan data dari Badan Pusat Statistik, persentase judul film dengan genre drama mendapatkan nilai sebesar 24,02\% pada tahun 2017 dan mengalami peningkatan pada tahun 2018 menjadi 41,34\%. Pada tahun 2017, film dengan genre komedi mendapat nilai sebesar $10,75 \%$ dan mengalami sedikit penurunan pada tahun 2018 menjadi 10,14\%. Dari data tersebut, terlihat bahwa film dengan genre drama dan komedi relatif cukup menarik perhatian khalayak (Badan Pusat Statistik, 2020).

Pada tanggal 18 Juni 2021, Netflix merilis film drama komedi yang berjudul Fatherhood. Film Fatherhood diadaptasi dari kisah memoar berjudul Two Kisses for Maddy: A Memoir of Loss and Love. Film yang disutradarai oleh Paul Weitz dan ditulis bersama Dana Stevens ini menduduki peringkat pertama Netflix di 82 negara (Cicilia, 2021). Netflix merupakan penyedia layanan streaming bagi pelanggan dengan menawarkan berbagai variasi film, mulai dari serial TV, dokumenter dan film-film lainnya. Pelanggan dapat mengakses semua layanan yang diberikan Netflix tanpa terganggu dengan iklan. Layanan Netflix dapat diakses oleh pelanggan melalui berbagai perangkat seperti smart TV, smartphone, komputer, tablet (Utami, 2019).

Film Fatherhood menceritakan tentang seorang ayah bernama Matthew Logelin yang diperankan oleh Kevin Hart. Ia memiliki keluarga yang bahagia dan bersiap untuk menyambut kelahiran anaknya. Akan tetapi Matthew harus menjadi seorang ayah tunggal karena istrinya dinyatakan meninggal dunia satu hari setelah melahirkan. Dengan pengetahuan yang terbatas mengenai tugas seorang ibu, Matthew mulai menjalankan tugasnya sebagai orang tua tunggal (Pratiwi, 2021).

Gender menghasilkan sebuah dikotomi peran yang dilakukan oleh perempuan dan laki-laki. Perempuan dengan sifat femininnya berperan dalam sektor domestik, sedangkan laki-laki dengan sifat maskulinnya berperan dalam sektor publik (Rokhmansyah, 2016). Peran pada sektor publik melibatkan kegiatan pencarian nafkah dan sektor domestik melibatkan kegiatan pengasuhan anak. Seorang ayah menjadi kurang terlibat dalam sektor domestik hingga pada akhirnya menjadi tantangan bagi seorang ayah tunggal untuk dapat mengasuh anak dan memiliki tuntutan untuk memenuhi tanggung jawab tersebut sebagai akibat dari pembagian peran domestik dan publik (Montezuma dan Lentari, 2020).

Dalam Fatherhood digambarkan seorang laki-laki yang secara umum memiliki sifat maskulin tetapi ia berperan dalam sektor domestik dengan melakukan pekerjaan rumah tangga dan mengurus anak perempuan seorang diri sekaligus berperan di sektor publik dengan mencari nafkah sebagai arsitek. 
Maskulinitas merupakan sebuah konstruksi kelaki-lakian terhadap laki-laki dan nilai-nilai yang diutamakan dalam maskulinitas secara umum menurut Barker dalam Wandi adalah kekuasaan, kekuatan, kendali, mandiri dan kerja. Hubungan interpersonal, kehidupan domestik, kelembutan, perempuan dan anak-anak dianggap hal yang dipandang rendah (Wandi, 2015: 248-249). Konsep maskulinitas telah mengalami perkembangan seiring perkembangan zaman. Maskulinitas menurut Beynon dalam Kusuma dan Sari berubah setiap empat dekade waktu dari maskulin sebelum tahun 1980 hingga maskulin pada tahun 2000. Sifat-sifat maskulinitas berdasarkan perubahan setiap empat dekade antara lain: Be a Big Wheel, No Sissy Stuff, Be a Sturdy Oak, Give em Hell, New Man as Narcissist, New Man as Nurturer, sifat laki-laki yang macho dan hooliganism, laki-laki metroseksual mengagungkan fashion (Kusuma dan Sari, 2019: 551).

Berdasarkan pemaparan latar belakang di atas, penulis tertarik untuk mengetahui representasi maskulinitas pada sosok ayah dalam film Fatherhood melalui tanda yang diperlihatkan dalam film menggunakan teori semiotika Roland Barthes terdiri dari denotasi, konotasi dan didukung oleh mitos.

\section{Metode Penelitian}

Penelitian yang dilakukan penulis bertujuan untuk mengetahui representasi maskulinitas pada sosok ayah dalam film Fatherhood. Dalam penelitian ini penulis menggunakan metode penelitian kualitatif deskriptif. Penelitian kualitatif menurut Moleong adalah penelitian bersifat deskriptif untuk memahami fenomena yang dialami oleh subjek penelitian dan dijelaskan dalam bentuk kata-kata dan bahasa (Moleong, 2016). Penelitian kualitatif deskriptif mendeskripsikan suatu objek, latar sosial, dan fenomena dijelaskan dalam tulisan bersifat naratif. Penulisan data berupa fakta yang diungkap akan menjadi dukungan terhadap penyajian data dalam laporan penelitian (Anggito dan Setiawan, 2018).

Penelitian ini menggunakan metode semiotika Roland Barthes. Semiotika adalah metode analisis untuk mengkaji sebuah tanda (Sobur, 2020). Model semiotik Roland Barthes merupakan signifikasi dua tahap. Hubungan signifier dan signified dalam tanda yang disebut sebagai denotasi merupakan tahap signifikasi pertama. Penggambaran interaksi yang terjadi ketika tanda bercampur dengan emosi dan hal ini disebut sebagai konotasi sebagai tahap signifikansi kedua. Pada signifikasi tahap kedua, tanda akan bekerja melalui mitos (Wibowo, 2013).

Subjek penelitian adalah subjek yang menjadi target oleh peneliti menjadi sasaran penelitian (Nurdin dan Hartati, 2019). Subjek penelitian dalam penelitian penulis adalah representasi maskulinitas pada sosok ayah melalui adegan-adegan dalam film Fatherhood. Objek penelitian menurut Spradley dalam Sugiyono merupakan pelaku, tempat serta aktivitas yang berinteraksi secara sinergis dan dinamakan sebagai situasi sosial (Sugiyono, 2012). Objek penelitian dalam penelitian penulis adalah adegan atau teks film Fatherhood yang menurut penulis mengandung representasi maskulinitas.

Data dalam penelitian diperoleh melalui metode pengumpulan data melalui data primer yaitu, adegan-adegan atau teks dalam film dan data sekunder berupa, observasi pada film, dokumentasi, dan studi kepustakaan.

Teknik analisis data kualitatif menurut Bogdan dan Biklen dalam Lexy J. Moleong merupakan analisis data dilakukan melalui organisasikan data, memilahmilah menjadi data yang dapat dikelola, mensintesis data, mencari sehingga 
menemukan pola, menemukan suatu hal yang penting dan dapat dipelajari hingga akhirnya terdapat suatu hasil penelitian bagi orang lain (Moleong, 2016). Penulis menggunakan semiotika model Roland Barthes sebagai teknik analisis yang terdiri dari denotasi, konotasi, dan mitos untuk memahami representasi maskulinitas pada sosok ayah dalam film "Fatherhood".

Dalam penelitian ini penulis melakukan beberapa tahap:

1. Menonton keseluruhan adegan dalam film Fatherhood

2. Penulis melakukan teknik purposive sampling dengan memilih sebelas adegan yang terdapat dalam film Fatherhood.

3. Penulis mengidentifikasikan tanda-tanda atau simbol yang terdapat dalam adegan-adegan film Fatherhood mengacu pada representasi maskulinitas pada sosok ayah dalam film tersebut.

4. Penulis melakukan tangkapan layar adegan yang merepresentasikan maskulinitas dalam film tersebut.

5. Melalui hasil pengamatan film tersebut penulis akan menganalisis tanda atau simbol dalam film dengan analisis semiotika Roland Barthes yang terdiri dari denotasi, konotasi, dan mitos.

\section{Hasil Temuan dan Diskusi}

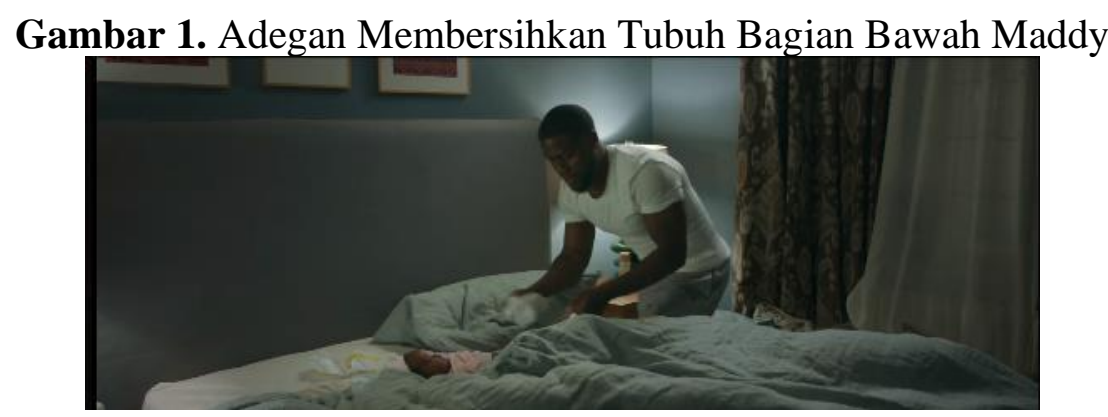

Sumber: Film Fatherhood

Denotasi pada adegan ini (Gambar 1) menunjukkan Matthew sedang membersihkan tubuh bagian bawah Maddy menggunakan tisu. Matthew membersihkan tubuh Maddy di atas ranjang dan terdapat popok yang sudah kotor di atas ranjang.

Konotasi pada adegan ini menunjukkan Matthew yang sedang mengurus anaknya dengan membersihkan tubuh Maddy.

Mitos yang terdapat dalam adegan ini adalah mengganti popok umumnya merupakan pekerjaan domestik yang dilakukan oleh ibu. Pekerjaan domestik berupa pengasuhan anak menjadi tanggung jawab perempuan akibat anggapan bahwa perempuan tidak pantas menjadi kepala rumah tangga karena sifat memelihara yang dimilikinya (Fakih, 2013). Menggantikan popok sekaligus membersihkan tubuh bayi merupakan kebutuhan fisik-biologis dalam hal kebersihan sebagai kebutuhan dasar seorang anak untuk tumbuh kembang (Wijaya, 2011). Peran ayah secara tradisional menurut Feldman dalam Supriyanto merupakan "penyedia" yang baik mengindikasikan bahwa ayah kurang terlibat dalam pengasuhan anak atau perawatan dibandingkan dengan perempuan. Masih dalam sumber yang sama dikatakan Coleman dan Garfield padahal peran ayah lebih dari sekedar pencari nafkah atau penyedia sebab ayah dapat ikut berperan dalam pengasuhan anak dan bertanggung jawab dalam merawat anak (Supriyanto, 2015). Adegan ini menunjukkan Matthew sebagai ayah 
Winardi Aldrian, Suzy S. Azeharie: Representasi Maskulinitas pada Sosok Ayah dalam Film (Studi Semiotika Roland Barthes pada Film Fatherhood)

melakukan pekerjaan domestik menggantikan tanggung jawab perempuan yaitu mengasuh anak dengan mengganti popok terhadap bayi.

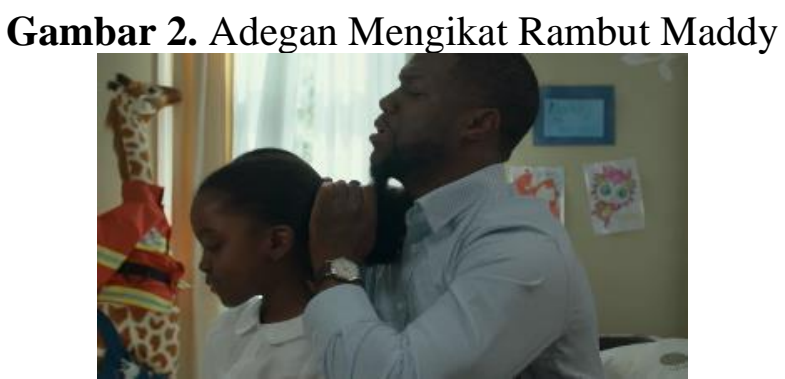

Sumber: Film Fatherhood

Denotasi pada adegan ini (Gambar 2) adalah Matthew sedang mengikat rambut Maddy di sebuah kamar.

Konotasi pada adegan ini menunjukkan Matthew yang berusaha untuk mengurus Maddy dengan mengikat rambutnya sebelum pergi ke sekolah.

Mitos dalam adegan ini adalah menyisir rambut termasuk dalam pengasuhan ibu karena dengan sentuhan dapat meningkatkan hubungan antara ibu dan anak. Ibu akan lebih sering untuk menyentuh dan mengelus rambut anak ketika menyisir rambutnya dan terjadinya kontak fisik akan berpengaruh pada ikatan emosional yang terjadi antara ibu dan anak serta membuka kesempatan untuk menjalin hubungan yang lebih dekat dengan terjadinya interaksi (Brooks dan McNair, 2014). Dalam adegan ini Matthew sebagai ayah menyisir rambut Maddy menggantikan pengasuhan yang dilakukan oleh ibu.

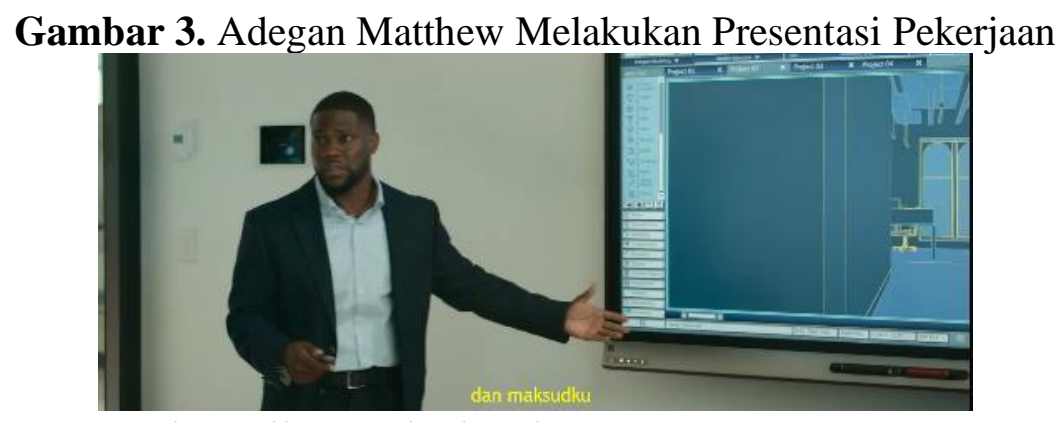

Sumber: Film "Fatherhood"

Denotasi pada adegan ini (Gambar 3) adalah Matthew yang sedang melakukan presentasi mengenai pekerjaan sebagai seorang arsitek kepada klien.

Konotasi pada adegan ini adalah Matthew sebagai sosok ayah yang berperan dan bertanggung jawab dalam kegiatan mencari nafkah.

Mitos yang terdapat dalam adegan ini adalah sosok ayah memiliki peran dalam kegiatan publik yaitu sebagai pencari nafkah. Peran publik menurut Achmad Muthali'in dalam Alfian Rokhmansyah merupakan hasil konstruksi budaya yang menempatkan laki-laki dengan sifat maskulin sebagai sudah sepantasnya melakukan peran tersebut (Rokhmansyah, 2016: 9). Kegiatan pencarian nafkah termasuk dalam keterlibatan ayah dalam pengasuhan anak menurut Hart dalam Parmanti dan Purnamasari sebagai economic provider yaitu ayah dianggap menjadi pendukung finansial dan pelindung keluarga (Parmanti dan Purnamasari, 2015: 83). 
Gambar 4. Adegan Pandangan Marion terhadap Matthew

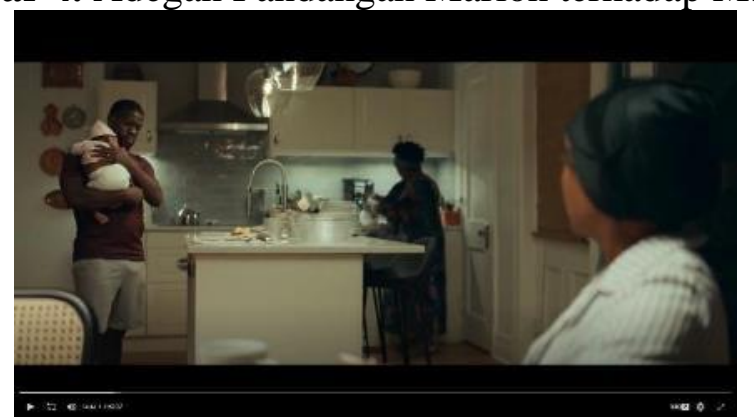

Sumber: Film Fatherhood

Denotasi dari adegan tersebut (Gambar 4) menunjukkan Matthew yang sedang menggendong Maddy menuju dapur untuk memberikannya susu.

Konotasi dari adegan tersebut menunjukkan Matthew yang memiliki rasa tanggung jawab terhadap pekerjaannya dan mertua yang merasa peduli pada menantu dan anaknya dan menganggap dirinya telah memikirkan hal terbaik selain meragukan menantunya mampu merawat dan mengurus anak seorang diri.

Mitos yang bekerja dalam adegan ini adalah adanya pembagian peran publik dan peran domestik berdasarkan gender. Perempuan dengan sifat femininnya berperan dalam domestik sementara laki-laki dengan sifat maskulinnya berkiprah di domain publik (Rokhmansyah, 2016: 9). Perempuan yang mengerjakan pekerjaan domestik dinilai dan dianggap lebih rendah dibandingkan dengan pekerjaan yang dilakukan lakilaki akibat bias gender yang menimbulkan beban kerja terhadap perempuan (Fakih, 2013: 21).

Pandangan Marion berkaitan dengan ideologi patriarki privat yang menempatkan perempuan bertugas penuh pada produksi rumah tangga sedangkan lakilaki ditempatkan pada publik. Patriarki privat merupakan bentuk patriarki yang menjadikan domain domestik yaitu produksi rumah tangga dan keluarga sebagai arena utama penindasan terhadap perempuan. Patriarki publik merupakan bentuk patriarki penguasaan pada domain publik seperti pekerjaan (Walby, 2014: 268).

\section{Simpulan}

Berdasarkan hasil diskusi dan pembahasan, terdapat beberapa kesimpulan sebagai hasil dari penelitian penulis antara lain:

1. Penulis merangkum bahwa maskulinitas pada sosok ayah dalam film "Fatherhood" direpresentasikan melalui tiga hal, yaitu peran domestik yang berhubungan dengan konsep maskulinitas laki-laki sebagai "new man as nurturer" dan fatherhood, peran publik yang merupakan peran laki-laki dengan maskulinitasnya dan pandangan masyarakat yang berkaitan dengan ideologi patriarki.

2. Konsep maskulinitas tidak ditentukan hanya melalui fisik seorang laki-laki melainkan terdapat karakter, norma dan nilai yang dibangun budaya masyarakat yang berbeda-beda dan bersifat dinamis sehingga mengalami perubahan seiring perkembangan zaman. 
Winardi Aldrian, Suzy S. Azeharie: Representasi Maskulinitas pada Sosok Ayah dalam Film (Studi Semiotika Roland Barthes pada Film Fatherhood)

\section{Ucapan Terima Kasih}

Penulis mengucapkan terima kasih sebesar-besarnya kepada seluruh pihak yang telah membantu dan mendukung penulis dalam proses penelitian ini dari awal hingga terbitnya publikasi atas hasil penelitian ini.

\section{Daftar Pustaka}

Angela, Michele dan Septia Winduwati. (2019). Representasi Kemiskinan Dalam Film Korea Selatan (Analisis Semiotika Model Saussure pada Film Parasite). Koneksi. 3(2). 478-484

Anggito, Albi dan Johan Setiawan. (2018). Metodologi Penelitian Kualitatif. Sukabumi: CV Jejak

Ardianto, Elvinaro, et al. (2012). Komunikasi Massa: Suatu Pengantar. Bandung: Simbiosa Rekatama Media

Badan Pusat Statistik. (2020). Persentase Judul Film yang Ditayangkan Oleh Perusahaan Bioskop Menurut Genre (Persen), 2014-2018. <https://www.bps.go.id/indicator/2/968/1/persentase-judul-film-yang-ditayan gkan-oleh-perusahaan-bioskop-menurut-genre.html> diakses pada 7 September 2021

Brooks, Wanda M. dan Jonda C. McNair. (2014). "Combing" through Representations of Black Girls's Hair in African American Children's Literature. Children's Literature in Education. 46. 296-307

Cicilia, Maria. (2021). "Fatherhood" Duduki Peringkat Pertama Netflix di 82 Negara. $<$ https://www.antaranews.com/berita/2233110/fatherhood-duduki-peringkatpertama-netflix-di-82-negara> diakses pada 6 September 2021

Fakih, Mansour. (2013). Analisis Gender dan Transformasi Sosial. Yogyakarta: Pustaka Pelajar

Kusuma, Shafira Nusa dan Wulan Purnama Sari. (2019). Gambaran Maskulinitas melalui Film (Studi Pandangan Generasi Milenial pada Tokoh Dilan di Film "Dilan 1990"). Koneksi. 2(2). 548-555

Moleong, Lexy J. (2016). Metodologi Penelitian Kualitatif. Bandung: PT Remaja Rosdakarya

Montezuma, Christabel Davina Fidelia dan Fransisca Rosa Mira Lentari. (2020). Gambaran Dimensi dari Fathering Self-efficacy pada Ayah Tunggal yang mengasuh anak usia dini. Philanthropy: Journal of Psychology. 4(1). 1-24

Nurdin, Ismail dan Sri Hartanti. (2019). Metodologi Penelitian Sosial. Surabaya: Media Sahabat Cendekia

Parmanti dan Santi Esterlita Purnamasari. (2015). Peran Ayah dalam Mengasuh Anak. InSight. 17(2). 81-90

Pratiwi, Mutiara Hening. (2021). Sinopsis Fatherhood, saat Kevin Hart Jadi Ayah Tunggal, Segera di Netflix. <https://www.kompas.com/hype/read/ 2021/05/18/112649466/sinopsis-fatherhood-saat-kevin-hart-jadi-ayah-tunggal -segera-di-netflix> diakses pada 6 September 2021

Rokhmansyah, Alfian. (2016). Pengantar Gender dan Feminisme: Pemahaman Awal Kritik Sastra Feminisme. Yogyakarta: Penerbit Garudhawaca

Sobur, Alex. (2020). Semiotika Komunikasi. Bandung: PT Remaja Rosdakarya

Sugiyono. (2012). Metode Penelitian Bisnis (Pendekatan Kuantitatif, Kualitatif, dan $R \& D)$. Bandung: Alfabeta 
Supriyanto. (2015). Peran dan Keterlibatan Ayah Dalam Pengasuhan. <https://lakilakibaru.or.id/peran-dan-keterlibatan-ayah-dalam-pengasuhan/> diakses pada 3 November 2021

Utami, Desy Budi. (2019). Mengenal Indonesia melalui Netflix. Jurnal Komunikasi. 11(1). 70-80

Walby, Sylvia. (2014). Teorisasi Patriarki (Mustika K. Prasela, Penerjemah). Yogyakarta: Jalasutra.

Wandi, G. (2015). Rekonstruksi Maskulinitas: Menguak Peran Laki-laki dalam Perjuangan Kesetaraan Gender. Journal of Gender Studies. 5(2). 239-255

Wibowo, Indiwan Seto Wahyu. (2013). Semiotika Komunikasi: Aplikasi bagi Penelitian dan Skripsi Komunikasi. Jakarta: Mitra Wacana Media

Wijaya, Awi Muliadi. (2011). Kebutuhan Dasar Anak Untuk Tumbuh Kembang yang Optimal. <https://kesmas.kemkes.go.id/konten/133/0/021113-kebutuhan dasar-anak-untuk-tumbuh-kembang-yang-optimal\#> diakses pada 3 November 2021. 